\title{
JUAL BELI BENDA WAKAF UNTUK PEMBANGUNAN MASJID ISTIQLAL DI DESA PALENGAAN DAJA PAMEKASAN
}

\author{
Mohammad Suyudi, Erie Hariyanto \\ IAIN Madura | Jl. Raya Panglegur Km. 4 Pamekasan \\ yudibaru85@gmail.com
}

\begin{abstract}
Muslim jurists agree that selling waqf property is forbidden A case happened when concrete pillars of a waqf mosque was sold in a mosque called Istiqlal in Daja village. The pillars were initially planned to be installed during rebuilding of the mosque. The research discovered that this pillar originated from charity. These pillars were re-sold to collect more fund from community to continue the rebuilding. Majority of sunni schools of law (Shafii, Maliki and Hanbali) view that such transaction is forbidden because there is no valid reason for selling the pillar. In addition, the seller is not the rightful person to do so. Meanwhile, Hanafi jurists allow such practice as long as all requirements are met, especially the availability of replacement property as well as fulfilment of all terms and conditions of selling.
\end{abstract}

Key words: Waqf, selling peoperty, mosque

Abstrak: Dalam masalah penjualan benda wakaf, para ulama sepakat bahwa hukum asal penjualan benda wakaf dilarang, kecuali memenuhi syarat-syarat benda wakaf yang dapat diperjualbelikan. Praktik jual beli benda berupa tiang masjid terjadi di Masjid Istiqlal Desa Palengaan Daja, yang pada dasarnya tiang tersebut baru dibangun dan akan digunakan sebagai penyangga utama pembangunan ulang masjid Istiqlal Desa Palengaan Daja yang sedang dalam tahap pembangunan ulang. Tulisan ini bertujuan untuk menjelaskan praktik jual beli benda wakaf dan pandangan hukum Islam terhadapnya di masjid Istiqlal Desa Palengaan Daja. Penelitian ini dilakukan dengan pendekatan kualitatif jenis deskriptif. Data dikumpulkan dengan metode observasi, wawancara dan dokumentasi dengan analisis menggunakan perpanjangan keikutsertaan, ketekunan pengamatan dan triangulasi. Hasil penelitian menunjukkan bahwa, Pertama, praktik jual beli benda wakaf di masjid Istiqlal Desa Palengaan Daja berawal dari adanya sumbangan untuk membangun ulang masjid tersebut, yang pada tahap awal pembangunan dapat menyelesaikan pondasi masjid dan beberapa tiang sebagai penyangga.

AL-DAULAH: JURNAL HUKUM DAN PERUNDANGAN ISLAM VOLUME 8, NOMOR 1, APRIL 2018

p-ISSN 2089-0109; e-ISSN 2503-0922

Homepage: http://jurnalfsh.uinsby.ac.id/index.php/aldaulah

Email: judulsj@gmail.com 
Kemudian tiang-tiang tersebut dijual kepada masyarakat untuk mendapatkan dana tambahan dalam melanjutkan pembangunannya. Kedua, pandangan hukum Islam tehadap jual beli benda wakaf di masjid Istiqlal Desa Palengaan Daja merupakan transaksi yang tidak diperbolehkan dalam pandangan ulama madzhab Syafi'i, Hambali dan Maliki, dikarenakan tidak ada alasan yang dapat menjadikan sebab untuk kebolehan dalam menjual benda wakaf tersebut serta penjual bukan orang yang memiliki hak atas benda yang dijual. Sedangkan menurut ulama Hanafi diperboelhkan karena memenuhi syarat untuk dilakukannya penjualan benda wakaf, yakni ada benda yang menjanjikan sebagai gantinya dan juga sudah memenuhi syarat dan rukun jual beli.

Kata Kunci: Jual Beli, Benda Wakaf, Masjid.

\section{Pendahuluan}

Wakaf merupakan perbuatan hukum seseorang atau sekelompok orang atau badan hukum yang memisahkan sebagian dari benda miliknya dan melembagakannya untuk selama-lamanya guna kepentingan ibadah atau keperluan umum lainnya sesuai dengan ajaran Islam. ${ }^{1}$ Dalam Islam, wakaf merupakan salah satu perbuatan yang dianjurkan dan bahkan memiliki manfaat yang sangat besar bagi pelakunya. Allah menjanjikan pahala yang senantiasa mengalir baginya meskipun ia telah meninggal dunia. Hal ini didasarkan pada adanya hadis tentang terputusnya amal, di mana setelah manusia meninggal dunia akan terputus segala amalnya tiga perkara yang diantara salah satunya adalah sedekah jariyah (wakaf). ${ }^{2}$

Di sisi lain terkait dengan adanya anjuran untuk melakukan wakaf, jika suatu benda atau barang telah diwakafkan oleh seseorang maka benda tersebut tidak diperbolehkan untuk dipindah tangankan dalam bentuk apapun, termasuk dalam larangan ini adalah memperjual belikan benda wakaf itu sendiri. Larangan ini sesuai dengan saran yang diberikan Rasulullah pada

\footnotetext{
I Intruksi Presiden R.I. Nomor I Tahun 1991 Kompilasi Hukum Islam di Indonesia, (Jakarta: t.p, 2000), 99.

2 Muslim, Shahih Muslim 2, dalam Ensiklopedia Hadits 4: Shahih Muslim 2, ed. Masyhari, et. Al. (Jakarta: Almahira, 20।2), 7I-72.
} 
Umar bahwa benda wakaf tidak boleh dijual belikan, diwariskan dan dihibahkan. ${ }^{3}$

Dalam pandangan ulama madzhab Syafi'i, menetapkan beberapa prinsip terkait dengan wakaf yang diantaranya adalah bahwa harta wakaf tidak boleh di jual, dihibahkan dan tidak boleh dipusakakan, harta wakaf tidak boleh ditarik balik (bersifat kekal) dan hasil atau manfaat harta wakaf adalah untuk kebajikan. ${ }^{4}$

Namun di sisi lain, Ibnu Qudamah berpendapat bahwa menjual benda wakaf dapat dilakukan apabila benda wakaf tersebut rusak, berkurang atau tidak memenuhi fungsinya sebagai benda wakaf dengan hasil penjualan tersebut digunakan untuk membeli barang lain yang nantinya dapat diambil manfaatnya sebagai benda wakaf. ${ }^{5}$

Pada bulan Maret 2017 di Desa Palengaan Daja terjadi kontroversi antara masyarakat yang satu dengan yang lainnya, tepatnya masyarakat di Dusun Angsokah Timur Desa Palengaan Daja Kecamatan Palengaan Kabupaten Pamekasan. Di mana hal tersebut terjadi karena adanya praktik jual beli benda wakaf di Masjid Istiqlal Desa Palengaan Daja, yang pada dasarnya sebagian masyarakat tidak menyetujuinya dengan menolak untuk membeli dan sebagian yang lain menyetujuinya dengan bersedia membeli benda wakaf yang diperjualbelikan.

Praktik jual beli benda wakaf yang dimaksud adalah berupa tiang masjid yang keadaannya masih baru dibangun dari hasil sumbangan masyarakat, di mana pada dasarnya tiang tersebut akan digunakan sebagai penyangga dari masjid Istiqlal Desa Palengaan Daja yang masih dalam tahap pembangunan ulang untuk direnovasi total. Hal tersebut telah dilakukan oleh pengurus masjid dengan masyarakat setempat selaku pembelinya, di mana dilakukannya transaksi tersebut bertujuan untuk mendapatkan

\footnotetext{
$3 \mathrm{lbid}$.

${ }^{4}$ Lukman Haji Abdullah, "Istibdal Harta Wakaf Dari Perspektif Mazhab Syafi'E", Jurnal Figh, 7 (20 I 0), 74-75.

${ }^{5}$ Hendi Suhendi, Fiqih Muamalah, ed-I, cet-VIII (Jakarta: Rajawali Pers, 20I3), 246.
} 
dana tambahan yang dapat digunakan sebagai dana untuk membeli bahan lain dalam melanjutkan pembangunannya. ${ }^{6}$

Dari permasalahan di atas, tulisan ini akan menjawab persoalan berikut: Pertama, bagaimana praktik jual beli benda wakaf di Masijid Istiqlal Desa Palengaaan Daja Palengaan Pamekasan. Kedua, bagaimana perspektif hukum Islam terhadap jual beli benda wakaf di Masjid Istiqlal Desa Palengaan Daja Palengaan Pamekasan.

\section{Kedudukan Benda Wakaf dalam Islam}

Secara etimologi kata wakaf berasal dari bahasa Arab waqafa, yang artinya menahan, berhenti, diam ditempat atau tetap berdiri. ${ }^{7}$ Waqafa dalam bahasa Arab memiliki arti yang sama dengan kata habasa, yang artinya menahan. Begitu juga dengan kata al-waqfu, dalam bahasa Arab memiliki makna yang sama dengan kata altahbis dan kata al-tasbil, yaitu menahan, menahan harta untuk diwakafkan, tidak dipindah milikkan. ${ }^{8}$

Secara istilah ulama madzhab memberikan definisi yang berbeda-beda. Menurut Imam Hanafi, bahwa wakaf adalah menahan suatu benda yang menurut hukum tetap milik orang yang mewakafkan dan menyedekahkan manfaatnya untuk tujuan kebaikan. Sementara Imam Syafi'i dan Imam Hambali mendefinikan wakaf dengan menahan harta yang dapat diambil manfaatnya serta kekal zatnya dengan lepas penguasaan waqif dan dimanfaatkan pada sesuatu yang diperbolehkan oleh agama atau dilakukan untuk jalan kebaikan dalam rangka mendekatkan diri kepada Allah. Mazhab Maliki menyatakan bahwa wakaf adalah pemilik harta menjadikan manfaat harta yang dimilikinya, walaupun yang dimilikinya berupa upah, atau menjadikan hasilnya

\footnotetext{
${ }^{6}$ AD, Masyarakat Angsokah Timur Palengaan Daja Palengaan Pamekasan, Wawancara langsung, (4 Juni 20 I7).

${ }^{7}$ Deprtemen Agama, Fiqih Wakaf, (Jakarta: Direktorat Pemberdayaan Wakaf Departemen Agama $\mathrm{Rl}, 2007)$, I.

8Wahbah Zuhayly, al-Fiqh al-Islami wa Adillatuhu, vol. 8 (Damaskus: Dar al-Fikr, I 985), I 53-I 55.
} 
untuk dapat digunakan seperti uang, wakaf dilakukan dengan diucapkan untuk masa tertentu sesuai dengan keinginan pemilik. ${ }^{9}$

Wakaf itu sendiri merupakan hal yang diperbolehkan dalam Islam, sebagaimana dalil yang terdapat dalam Al-Quran surah AlImran ayat 92 yang artinya:

"Kamu sekali-kali tidak sampai kepada kebajikan (yang sempurna), sebelum kamu menafkahkan sebagian harta yang kamu cintai. dan apa saja yang kamu nafkahkan Maka Sesungguhnya Allah mengetahuinya". (Q.S. Al-Imran : 92). ${ }^{10}$

Selain itu juga terdapat dalam hadits yang diriwayatkan oleh Imam Muslim dari Abu Hurairah Ra., bahwa Rasulullah SAW bersabda:

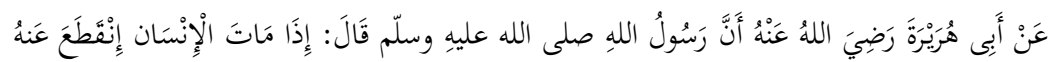

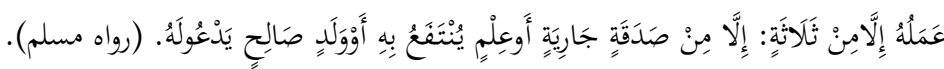

"Jika manusia meninggal, maka amalnya terputus kecuali dari tiga perkara; sedekah jariyah, ilmu yang bermanfaat, dan doa anak shaleh baginya". (HR. Muslim). ${ }^{11}$

Sebelum membahas pendapat para ulama terkait dengan hukum menjual benda wakaf, ada dua istilah dalam jual beli benda wakaf, yakni ibdâl dan istibdâl. Ibdaâl adalah perbuatan menjual benda wakaf untuk membeli benda lain sebagai ganti dari benda wakaf tersebut. Sementara Istibdâl adalah perbuatan menjadikan benda tertentu sebagai pengganti benda wakaf asli yang telah dijual. ${ }^{12}$

9M. Khoirul Hadi Al-Asy'ari, "Pandangan Ibn Qudamah Tentang Wakaf Dan Relevansinya Dengan Wakaf Di Indonesia", Li Falah Jurnal Studi Ekonomi dan Bisnis Islam, I (Juni, 20 I6), 56.

${ }^{10}$ Departemen Agama, al-Quran Perkata dan Tajwid Warna Rabbani, (Jakarta: PT. Surya Prisma Sinergi, 20I2), 63.

"'Muslim, Shahih Muslim 2, dalam Ensiklopedia Hadits 4: Shahih Muslim 2, ed. Masyhari, et. Al. (Jakarta: Almahira, 20 I2), 7|-72.

${ }^{12}$ Ayudin, "“Hukum Jual Beli Harta Wakaf Dalam Perspektif Empat Imam Madzhab (Imam Maliki, Imam Hanafi, Imam Shafi'i dan Imam Hambali)", Maqosid, 2 (Juli, 20I6), 67. 
Adapun pandangan ulama madzhab terkait dengan hukum penjualan dan penukaran benda wakaf adalah sebagai berikut Dalam pandangan madzhab Syafi'i, mayoritas mereka melarang penjualan maupun penukaran benda wakaf. Menurut mereka benda wakaf tetap harus diambil manfaatnya sampai benar-benar habis. Bahkan jika benda wakaf telah rusak, menurut Imam Nawawi benda wakaf tersebut dibiarkan begitu saja. ${ }^{13}$

Selain itu, menurut Syarbini, Syairazi, Imam Syafi'i pribadi dan jumhur ulama dari kalangan madzhab Syafi'i menyatakan bahwa benda wakaf dilarang untuk diperjual belikan. Namun jika seandainya benda wakaf itu bisa diambil manfaatnya dengan menjadikan sebagai kayu bakar, maka boleh memanfaatkannya dengan cara tersebut. ${ }^{14}$

Al-Mawardi berpendapat bahwa benda wakaf tidak bergerak tidak boleh dijualbelikan, dikarenakan masih ada kemungkinan untuk diperbaiki. Adapun jika benda wakaf berupa benda bergerak yang tidak bisa memberikan manfaat lagi, maka dalam hal ini senada dengan pendapat Al-Ramli bahwa benda tersebut boleh dijual untuk menghilangkan kemubadziran. ${ }^{15}$

Dalam menghukumi penjualan benda wakaf, madzab Maliki membedakan antara benda bergerak dengan benda tidak bergerak. Pendapat yang masyhur di kalangan madzhab Maliki adalah boleh menjual benda wakaf bergerak. Hal itu dapat dilakukan jika benda yang dimaksud sudah tidak dapat diambil manfaatnya lagi seperti baju yang rusak. Namun selama benda wakaf masih dapat diambil manfaatnya meskipun bukan orang yang dituju sebagai orang yang berhak menerima wakaf, maka hal itu tidak diperbolehkan untuk dijual seperti buku wakaf yang sudah tidak dipakai lagi boleh diberikan kepada orang lain untuk menggunakannya tanpa harus menjualnya. ${ }^{16}$

\footnotetext{
${ }^{13}$ Dahlia Haliah Ma'u, "Studi Analisis Terhadap Dinamika Pemikiran Fukaha Sunni Tentang Ibdâl Dan Istibdâl Benda Wakaf", Al-'Adalah, I (Juni, 2016), 57.

${ }^{14}$ Ayudin, "Hukum Jual Beli Harta Wakaf, 67-68.

${ }^{15}$ Dahlia, "Studi Analisis Terhadap Dinamika Pemikiran Fukaha, 57.

${ }^{16}$ Ayudin, "Hukum Jual Beli Harta Wakaf, 69-70.
} 
Sama hal nya dengan barang wakaf yang membutuhkan biaya perawatan yang besar maka boleh dijual dan diganti dengan barang yang tidak membutuhkan biaya perawatan yang memiliki spesifikasi sama atau minimal menyerupai barang wakaf asli. Seperti contoh kuda yang perlu perawatan diganti dengan senjata lain yang sama-sama bisa digunakan perang. ${ }^{17}$

Adapun berkaitan dengan benda wakaf tidak bergerak, maka dalam hal ini para ulama madzhab Maliki secara tegas melarang untuk menjualnya kecuali dalam keadaan darurat seperti tanah wakaf yang diperlukan sebagai pelebaran jalan. ${ }^{18}$ Maka dalam keadaan yang sedemikian rupanya boleh benda wakaf itu diperjualbelikan.

Jika benda wakaf tidak bergerak berupa masjid, maka sebagaimana yang dikemukakan oleh Al-Kalabi bahwa madzhab Maliki bersepakat atas kemutlakan dilarangnya penjualan masjid yang diwakafkan. ${ }^{19}$ Akan tetapi boleh dilakukan penukaran dengan benda yang sejenis. Misal, masjid dengan masjid dalam rangka melestarikan nilai wakaf dari masjid yang lama.20

Sedangkan selain masjid, madzhab Maliki melarang dengan ketat penjualan benda tersebut selama masih bisa diambil manfaatnya atau benda yang dalam keadaan tidak bisa memberikan manfaat akan tetapi masih ada kemungkinan bisa memberikan manfaat di masa yang akan datang. ${ }^{21}$

Adapun jika tidak ada harapan lagi untuk bisa diambil manfaatnya dikemudian hari, maka dalam hal ini ada yang membolehkan jika berada di luar kota, karena memiliki kesulitan dalam perbaikannya. Kebolehan tersebut dengan mengqiyaskan pada pakaian yang telah usang. Namun jika berada di dalam kota

\footnotetext{
17 Dahlia, "Studi Analisis Terhadap Dinamika Pemikiran Fukaha, 56.

18 Ayudin, "Hukum Jual Beli Harta Wakaf, 7I.

19 lbid, 56.

${ }^{20}$ Helmi Karim, Fiqih Muamalah, Ed. I, Cet. 2 (Jakarta: PT. Raja Grafindo Persada, 1997), I I 5.

21 Dahlia, "Studi Analisis Terhadap Dinamika Pemikiran Fukaha", 56.
} 
maka benda wakaf itu tidak boleh dijual, karena ada kemungkinan untuk diperbaiki. ${ }^{22}$

Dalam pendapat madzhab Hambali mengatakan bahwa hukum asal menjual benda wakaf adalah haram, tetapi hal itu diperbolehkan dalam kondisi darurat demi menjaga tujuan wakaf, yakni agar benda wakaf dapat dimanfaatkan oleh umat. ${ }^{23}$ Seperti benda wakaf rusak dan tidak menghasilkan apa-apa serta tidak dapat memberikan manfaat lagi bagi penerima wakaf, maka diperbolehkan untuk dijual dengan hasil penjualannya dibelikan benda lain sebagai gantinya. ${ }^{24}$

Termasuk dalam hal ini masjid yang rusak atau berada di daerah yang menyebabkan terhalangnya jamaah untuk menggunakannya, juga dapat diperjual belikan menurut pandangan ulama madzhab Hambali. ${ }^{25} \mathrm{Ibnu}$ Qudamah menyatakan pendapatnya dengan didasarkan pada kemaslahatan yang ada di dalamnya, dimana sangatlah tidak baik jika benda wakaf yang telah rusak dan tidak bisa memberikan manfaat lagi dibiarkan begitu saja tanpa ada tindakan positif terhadapnya. oleh karena itu, benda wakaf yang sudah rusak dan tidak dapat difungsikan lagi dapat diperjual belikan. ${ }^{26}$.

Dalam hal penjualan masjid, dalam madzhab Hambali ada yang membolehkannya sebagaimana pendapat Ibnu Taymiyah yang menyatakan bahwa jika masjid rusak dan tidak mungkin lagi difungsikan, maka boleh dijual dan hasilnya untuk membeli apa yang dapat menggantikannya. Karena jika yang asal tidak dapat mencapai tujuannya, maka diganti dengan benda lainnya. Misal membangun masjid baru yang lebih layak bagi masyarakat setempat, maka masjid yang lama dapat dijual.

Selain itu, ada pendapat dalam madzhab Hambali yang melarang penjualan masjid. Hal ini merujuk pada adanya riwayat

\footnotetext{
22 Ibid, $7 \mid-72$.

${ }^{23}$ Ayudin, "Hukum Jual Beli Harta Wakaf, 74.

${ }^{24}$ Dahlia, "Studi Analisis Terhadap Dinamika Pemikiran Fukaha, 57.

${ }^{25}$ Ayudin, "Hukum Jual Beli Harta Wakaf, 73.

${ }^{26}$ M. Khoirul Hadi Al-Asy'ari, "Pandangan Ibn Qudamah Tentang Wakaf, 60.
} 
yang melarang penjualan masjid, seperti perkataan Abu Bakar yang diriwayatkan oleh Ali bin Abu Said bahwa masjid tidak boleh dijual, yang dibolehkan hanya pemindahan perlengkapan yang terdapat di dalamnya. ${ }^{27}$

Dalam madzhab Hambali juga diterangkan bahwa yang berhak melakukan penjualan atau penukaran benda wakaf adalah hakim, jika wakaf tersebut ditujukan untuk umum. Namun jika wakaf tersebut ditujukan untuk orang-orang tertentu, maka yang berhak adalah Nadzir dengan memperoleh izin sebelumnya dari hakim. ${ }^{28}$

Dalam madzhab Hanafi, Ibdâl dan Istibdâl boleh dilakukan oleh siapa saja, baik benda bergerak maupun benda tidak bergerak. Pendapat mereka menitikberatkan pada kemaslahatan dan aspek kemanfaatan yang ada pada benda wakaf. ${ }^{29}$ Kebolehan tersebut dapat dilakukan dalam tiga kategori yang berbeda tentang keduanya yaitu: 1) ibdâl atau istibdâl disyaratkan oleh wâqif. 2) ibdâl/istibdâl tidak disyaratkan oleh waqif, baik ia memang tidak menyinggung sama sekali atau jelas-jelas melarangnya. Sedangkan di sisi lain, kondisi mauqûf (benda wakaf) sudah tidak dapat difungsikan dan dimanfaatkan lagi. 3) ibdâl/istibdâl tidak disyaratkan oleh wâqif, sedangkan mauqûf masih dalam keadaan terurus dan berfungsi, tetapi ada barang pengganti yang dalam kondisi menjanjikan. ${ }^{30}$

\section{Wakaf Masjid}

Secara bahasa masjid berasal dari bahasa Arab, yaitu "masjidun" yang memiliki arti tempat sujud. Kata tersebut merupakan isim makan dari kata "sajada, yasjudu, sujudan" yang berarti membungkuk dengan khikmat. ${ }^{31}$ Sementara secara istilah,

\footnotetext{
27 Dahlia, "Studi Analisis Terhadap Dinamika Pemikiran Fukaha, 57-58.

${ }^{28}$ Ayudin, "Hukum Jual Beli Harta Wakaf, 74-75.

29 Ibid, 75.

30 Dahlia, "Studi Analisis Terhadap Dinamika Pemikiran Fukaha, 55-56.

31 Syamsul Kurniawan, "Masjid dalam Lintasan Sejarah Umat Islam", Jurnal Khatulistiwa-Journal of Islamic Studies, 2 (September, 20 I4), 170.
} 
An-Nasafi menyatakan bahwa masjid adalah rumah yang dibangun khusus untuk shalat dan beribadah di dalamnya kepada Allah. Selain itu, Al-Qadhi Iyadh menyatakan bahwa masjid adalah semua tempat di muka bumi yang memungkinkan untuk menyembah dan bersujud kepada Allah. ${ }^{32}$

Masjid sebagai salah satu bentuk wakaf memiliki banyak bentuk shighat, yaitu: Pertama, sebidang tanah diwakafkan menjadi masjid, seperti perkataan wâqif "aku jadikan tempat ini sebagai masjid". Dengan itu, menurut pendapat yang kuat hukumnya secara langsung tanah yang dimaksud menjadi masjid meskipun tidak terdapat bangunan masjid, sehingga hamparan tanah itu diberlakukan hukum masjid, seperti haram bagi yang berhadats besar berdiam di tempat itu, dll. Kedua, wakaf tanah agar dibangun masjid, yakni wâaqif tidak menjadikan tanah yang dimaksud sebagai masjid, tetapi dimaksudkan agar di atas tanah itu dibangun masjid. Dengan demikian tanah yang diwakafkan tidak serta merta menjadi masjid, akan tetapi statusnya sebagai tanah wakaf. Ketiga, wakaf bangunan menjadi masjid, artinya tanah dan bangunan yang sudah jadi, diwakafkan menjadi masjid, baik bangunan tersebut model masjid atau tidak. Wakaf masjid model ini menjadikan tanah dan bangunan tersebut dihukumi masjid setelah shighat wakaf diucapkan. Keempat, menghimpun dana untuk pembangunan masjid, yakni mengumpulkan dana atau barang yang dapat menunjang pembangunan masjid, di mana uang atau barang yang terkumpul dari penyumbang digunakan untuk pembangunan masjid itu sendiri. Wakaf masjid model ini tidak memerlukan shighat, dikarenakan bangunan yang berdiri dari hasil sumbangan itu dengan sendirinya berlaku hukum masjid meskipun tidak terdapat shighat wakaf dari penyumbang maupun pengurus masjid, 
sebab setiap bahan material bangunan yang sudah terpasang dalam bangunan fisik masjid dengan sendirinya menjadi masjid. ${ }^{33}$

\section{Praktik Jual Beli Benda Wakaf di Masjid Istiqlal Desa Palengaan Daja}

Praktik penjualan benda wakaf di Masjid Istiqlal Desa Palengaan Daja dilakukan dengan motif agar benda yang dibeli menjadi wakaf penuh dari orang yang membelinya. Di mama praktik tersebut dilakukan untuk mendapatkan dana tambahan dalam melanjutkan pembangunan Masjid Istiqlal Desa Palengaan Daja.

Praktik jual beli benda wakaf di Masjid Istiqlal Desa Palengaan Daja berawal dari adanya sumbangan masyarakat dalam pembangunan ulang masjid tersebut untuk direnovasi total, di mana pembangunan yang dilakukan oleh panitia bersama masyarakat setempat secara bertahap-tahap sesuai dengan keadaan dana yang tersedia.

Pada tahap awal pembangunan masjid Istiqlal Desa Palengaan Daja, berhasil menyelesaikan pondasi dan \pm 15 tiang yang dapat ditegakkan yang kemudian pembangunan divakumkan seiring dengan kurangnya dana yang diperlukan untuk melanjutkan pembangunannya. Seiring dengan vakumnya pembangunan tersebut, penggalangan dana tetap dilakukan dan kemudian tiangtiang yang baru tegak tersebut ditawarkan kepada masyarakat untuk dijual, di mana hal tersebut dilakukan oleh salah satu panitia pembangunan masjid tersebut sebagai sarana untuk mendapatkan tambahan dana dalam menunjang pembangunan selanjutnya.

Dari adanya penawaran yang dilakukan oleh panitia pembangunan masjid Istiqlal Desa Palengaan Daja, terdapat dari masyarakat setempat yang membelinya dengan melakukan transaksi tawar menawar di depan Madrasah Nurul Istiqlal Desa Palengaan Daja. Di mana pihak penjual yang dalam hal ini diwakili

33 Muhibbul Aman Aly, Wakaf, Masjid, Pondok dan Madrasah, Artikel Keislaman, diakses dari ppssnh.malang.pesantren.web.id/cgi-bin/content.cgi/artikel/wakaf.singel, pada tanggal I5 Desember 2017 pukul 16.30 . 
oleh bendahara masjid menetapkan bahwa harga tiang yang lebih besar adalah Rp. 1.500.000,00 dan yang lebih kecil berharga Rp. 1.000.000,00. Sehingga dengan harga yang disepakati tersebut, masyarakat yang bersedia membelinya melakukan serah terima uang dengan bendahara masjid setelah melakukan pengamatan terhadap tiang yang dijualbelikan.

Serah terima uang yang dilakukan oleh penjual dan pembeli tersebut tidak disertakan dengan serah terima benda yang diperjualbelikan, di mana benda wakaf berupa tiang masjid yang sudah dibeli oleh masyarakat tidak diberikan kepada masyarakat selaku pembeli. Melainkan tetap pada tempat semula sesuai dengan motif dari adanya penjualan tersebut dan tetap akan dipergunakan sebagaimana fungsi awal, yakni sebagai penyangga dari masjid yang akan dibangun.

\section{Pandangan Hukum Islam Terhadap Jual Beli Benda Wakaf di Masjid Istiqlal Desa Palengaan Daja}

Wakaf merupakan salah satu dari beberapa amal perbuatan yang senantiasa mengalirkan pahala bagi orang yang melakukannya. Sesuai dengan sabda Nabi Muhammad saw:

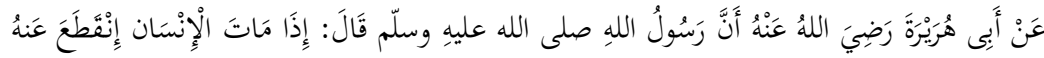

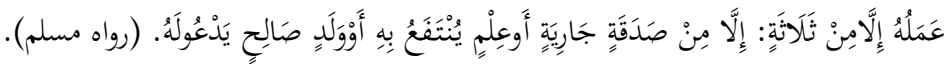

"Jika manusia meninggal, maka amalnya terputus kecuali dari tiga perkara; sedekah jariyah, ilmu yang bermanfaat, dan doa anak shaleh baginya". (HR. Muslim). ${ }^{34}$

Secara istilah wakaf merupakan perbuatan hukum seseorang atau sekelompok orang yang memisahkan setiap benda miliknya dan melembagakannya untuk selama-lamanya guna kepentingan ibadah atau keperluan umum lainnya sesuai dengan ajaran Islam. ${ }^{35}$

Dalam melakukan wakaf, terdapat beberapa rukun dan syarat yang harus dipenuhi. Di mana rukun dan syarat tersebut

${ }^{34}$ Muslim, Shahih Muslim 2, 71-72.

35 Intruksi Presiden R.I. Nomor I Tahun 1991, 99. 
merupakan penentu sah tidaknya wakaf yang dilakukan oleh seseorang. Jika melihat perwakafan yang dilakukan oleh para waqif kepada nadzir di masjid Istiqlal Desa Palengaan Daja dengan cara meminta sumbangan untuk pemangunan masjid, dapat diakatakan bahwa hal tersebut sudah memenuhi kriteria wakaf yang sah menurut hukum Islam.

Perihal tentang sahnya perwakafan yang dilakukan oleh wâqif pada nâdzir di masjid Istiqlal Desa Palengaan Daja di atas, dikarenakan uang atau barang yang disumbangkan akan digunakan sebagai sarana dalam memenuhi kebutuhan bahanbahan dalam pembangunan masjid itu sendiri. Di mana setiap sumbangan yang terkumpul untuk pembangunan masjid, baik uang atau barang yang menjadi bagian dari bangunan masjid, sudah berlaku atasnya hukum-hukum masjid yang pada dasarnya itu merupakan benda wakaf, meskipun dalam pengumpulannya dilakukukan tanpa diucapkan shighat dari pihak penyumbang atau nâdzirnya seperti hasil sumbangan masyarakat dibuat tiang masjid. ${ }^{36}$

Oleh karena itu, tiang yang diperjual belikan kepada masyarakat di masjid Istiqlal Desa Palengaan Daja termasuk ke dalam benda wakaf masjid. Hal itu dikarenakan tiang tersebut terbentuk dari hasil sumbangan masyarakat yang dikumpulkan dalam rangka pembangunan masjid Istiqlal itu sendiri. Berkaitan dengan membangun dan merenovasi masjid merupakan hal yang diperbolehkan dalam Islam, hal ini didasarkan pada firman Allah Taala dalam surah al-Taubah ayat 18:

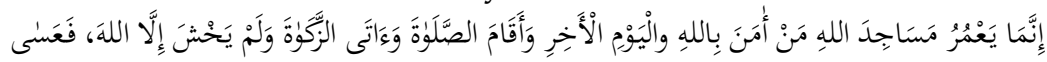

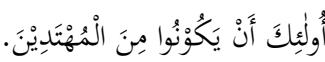

"Hanya yang memakmurkan masjid-masjid Allah ialah orang-orang yang beriman kepada Allah dan hari Kemudian, serta tetap mendirikan

36 Muhibbul Aman Aly, Wakaf, Masjid, Pondok dan Madrasah, Artikel Keislaman, diakses dari ppssnh.malang.pesantren.web.id/cgi-bin/content.cgi/artikel/wakaf.singel, pada tanggal I5 Desember 2017 pukul 16.30 . 
shalat, menunaikan zakat dan tidak takut (kepada siapapun) selain kepada Allah, Maka merekalah orang-orang yang diharapkan termasuk golongan orang-orang yang mendapat petunjuk". (Q.S. Al-Taubah: 18). ${ }^{37}$

Wajh al-dilâlah dari ayat ini bahwa Allah SWT menyebut orang yang memakmurkan masjid, asalkan memenuhi semua persyaratannya, digolongkan sebagai orang-orang yang mendapat petunjuk. Tetapi bagaimana kita bisa menjadi orang seperti itu, kalau masjid yang mau dimakmurkan malah tidak ada. Maka langkah paling awal dari ibadah memakmurkan masjid itu tidak lain adalah mulai dari mendirikan masjid. Ayat ini, selain memerintahkan untuk memakmurkan masjid, juga menjadi dalil atas perintah untuk sejak awal mendirikan masjid. ${ }^{38}$

Terlebih lagi masjid Istiqlal Desa Palengaan Daja yang akan direnovasi sudah sangat tua dan ditakutkan roboh, sehingga akan menyebabkan sesuatu yang dapat membayakan bagi jamaahnya. Oleh karena itu, perlu untuk direnovasi agar masyarakat lebih aman dalam melakukan perintah Allah swt. berupa memakmurkan masjid. Hal ini seagaimana hasil wawancara dengan informan:

“Dilakukannya renovasi masjid ini karena keadaan masjid yang sudah tidak layak pakai lagi, di mana sudah banyak gedung yang retak, gentengnya banyak yang bocor, dan keadaan kayu yang sudah tua membuat kami takut masjid itu roboh pada saat ada jamaah yang shalat di dalamnya." 39

Selain itu, terkait dengan akibat berbahayanya masjid tersebut terdapat perintah agama untuk menghilangkan kemudharatan itu sendiri, sebagaimana disabdakan oleh Rasulullah Shallallahu Alaihi Wasallam yang diriwayatkan oleh Imam al-Baihaqi dari Abu Said al-Khudri:

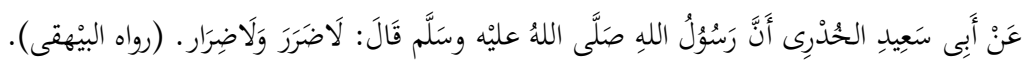

${ }^{37}$ Departemen Agama, al-Quran Perkata dan Tajwid Warna Rabbani, 190.

${ }^{38}$ Ahmad Sarwat, Seri Fiqih Kehidupan, 34-35.

39 MAL, Ketua Takmir Masjid Istiqlal, Wawancara Langsung, (07 November 20 I7). 
"Dari Abu Said al-Khudri, bahwasanya Rasulullah Shallahu Alaihi Wasallam bersabda: tidak ada modharat dan tidak boleh menimbulkan modharat". (H.R. al-Baihaqi).40

Di sisi lain, keberadaan dana yang cukup dalam membangun atau melakukan renovasi total masjid sangat diperlukan. Namun dalam melakukan penggalangan dana, panitia pembangunannya harus memperhatikan agar dilakukan dengan cara yang dibenarkan dalam Islam untuk mendapatkan dana yang benar-benar halal. Hal ini dikarenakan pada dasarnya Allah Taala tidak menerima sesuatu kecuali yang baik-baik. Sebagaimana hal tersebut ditentukan dalam hadits yang diriwayatkan oleh Imam Muslim:

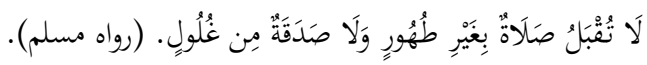

"Tidaklah shalat diterima tanpa bersuci dan shadaqah tidak diterima jika dari hasil ketidakjujuran". (H.R. Muslim).41

Semenatara itu, dalam praktik yang ada dalam pembangunan ulang masjid Istiqlal Desa Palengaan Daja dana yang dihasilkan oleh panitia pembangunannya adalah dana yang sebagiannya dihasilkan dari hasil meminta di jalanan.sebagaimana hasil observai peneliti yang menunjukkan bahwa masyarakat bergotong royong mencari dana pembangunan masjid yang dilakukan di jalanan, tepatnya di perbatasan Desa Palengaan Daja bagian timur yang dilakukan pada setiap hari Senin dan Jumat. Selain itu penggalangan dana di jalanan juga dilakukan setiap hari di Desa Palengaan Laok. ${ }^{42}$

Oleh karena itu hal tersebut merupakan hal yang tidak seharusnya dilakukan dalam mengumpulkan dana pembangunan sebuah masjid, dikarenakan dalam penggalangan dana pembangunan masjid yang dilakukan dengan cara meminta di jalanan memiliki beberapa sisi negatif, yang diantaranya: (1)

\footnotetext{
${ }^{40}$ Abu Bakar Ahmad bin Husain bin Ali al-Baihaqy, al-Sunan al-Kabir Juz 6, (Bairut: Dar al-Kutub alIImiyah, 2003), I| 4.

4I Muslim, Shahih Muslim I, dalam Ensiklopedia Hadits3: Shahih Muslim I, ed. Ferdinan Hasmand, et. Al., (Jakarta: Almahira, 20।2), 127.

42 Observasi Langsung, Senin 10 November 2017, Desa Palengaan Daja, Pukul 07.30 WIB.
} 
Menganggu lancarnya perjalanan yang berlawanan dengan prinsip Islam dalam hal menghilangkan kemudharatan; (2) Meminta-minta merupakan hal yang kurang dan tidak selaras dengan hukum Islam, dimana dalam Islam ditentukan bahwa memberi lebih baik dari pada menerima; (3) Menyalahi asas menjaga agama sebagai salah satu maqâshid al-syari'ah, di mana perbuatan tersebut terlihat bahwa Islam adalah agama yang rendah; (4) Adanya imbalan yang diperoleh oleh para pelaku secara prosentase dari dana yang dihasilkan, yang pada dasarnya hal tersebut adalah dana yang diniatkan oleh pemiliknya untuk pembangunan masjid. ${ }^{43}$

Selain itu, adanya penggalangan dana pembangunan masjid yang dilakukan dengan cara meminta di jalanan adalah pembungkusan aktivitas sosial atas nama agama. Di mana dengan adanya sisi negatif di dalamnya, terlihat baik karena dilakukan untuk mencari dana pembangunan suatu tempat ibadah yang disebut masjid. ${ }^{44}$

Dari adanya sisi negatif tersebut, maka dalam pencarian dana pembangunan masjid agar tidak dilakukan dengan cara meminta di jalanan. Karenanya, terselenggaranya pembangunan tersebut tidak ada hal yang dapat melecehkan Islam sebagai agama yang rahmatan lil alamin. Selain itu, dana yang digunakan dalam pembangunan ulang masjid Istiqlal Desa Palengaan Daja adalah hasil penjualan benda wakaf berupa tiang masjid yang masih baru dibangun, yang pada dasarnya penjualan tersebut dimaksudkan agar benda yang dibeli oleh masyarakat menjadi wakaf penuh dari masyarakat yang membelinya. Hal ini sebagaimana hasil wawancara berikut:

"Penjualan tiang masjid yang baru dibangun tersebut memang telah terjadi. Di mana dijualnya tiang tersebut untuk menambah dana dalam melanjutkan pembangunan dan semata-mata agar menjadi wakaf penuh dari orang yang membelinya. Adapun hasil dari penjualan tersebut digunakan untuk membeli bahan lain untuk

43 Wardi, “Pencarian Dana Masjid Di Jalan Raya, 335-336..

${ }^{44}$ Holis, "Konstruksi Masyarakat Pencari Sumbangan Di Jalan Raya, 8I. 
melanjutkan pembangunan Masjid Istiqlal. Hal itu dilakukan oleh panitia pembangunan Masjid, yakni BLQ" ${ }^{45}$

Pada dasarnya dari adanya hal yang demikian, praktik tersebut mengisyaratkan adanya seseorang yang membeli benda wakaf untuk diwakafkan kembali atas nama dirinya atau adanya sumbangan benda wakaf dari masyarakat yang membeli suatu benda, di mana pada dasarnya benda yang dibeli tersebut pada asalnya memang merupakan benda wakaf yang dihasilkan dari sumbangan masyarakat lainnya (untuk selanjutnya disebut dengan pengalihan nama wâaif).

Untuk mencari hukum dari adanya permasalahan tersebut, dapat dianalisis dengan cara bagaimana hukum Islam memandang transaksi yang digunakan sebagai sarana dalam pengalihan nama wâqif itu sendiri. Di mana dalam hal ini transaksi yang digunakan adalah akad jual beli.

Dalam hukum Islam, pada dasarnya penjualan benda wakaf merupakan hal yang dilarang. Hal ini didasarkan pada adanya hadist yang shahih, yakni hadits yang diriwayatkan oleh Imam Bukhori dan Muslim dari Ibnu Umar ra:

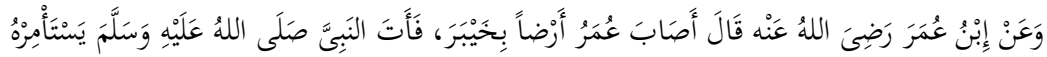

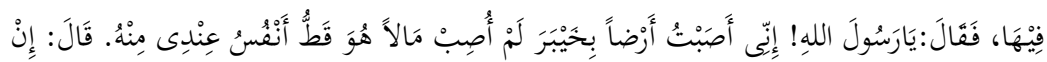

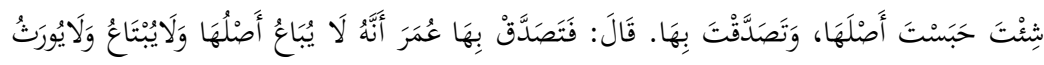

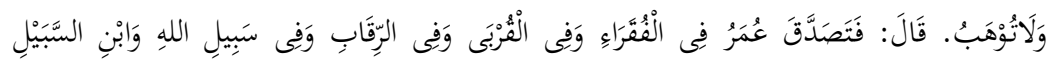

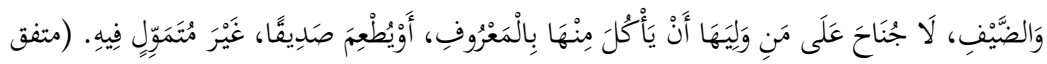

"Dari Ibnu Umar, ia berkata: "Umar Radliyallahu Anhu memperoleh bagian tanah di Khaibar, kemudian menghadap pada Rasulullah Shallallahu Alaihi Wasallam untuk meminta petunjuk dalam mengurusnya". Umar berkata: "Yaa Rasulullah, aku memperoleh sebidang tanah di Khaibar yang menurutku aku belum pernah memperoleh tanah yang lebih baik dari pada itu". Rasulullah bersabda: 
"jika engkau mau, tahanlah asalnya dan sedekahkan hasilnya". Ibnu Umar berkata: "Lalu Umar mewakafkannya dengan syarat pokoknya tidak boleh dijual, diwariskan, dan dihibahkan". Ibnu Umar berkata: "Umar menyedekahkan hasilnya pada kaum fakir, kaum kerabat, para hamba sahaya, orang yang berada dijalan Allah, ibnu sabil, dan tamu". Tidak ada dosa bagi pengelolanya untuk mengambil hasilnya dengan sepantasnya dan memberi makan sahabat, namun dengan tidak menyimpannya." (H.R. Bukhori Muslim). ${ }^{46}$

Dalam hadits tersebut dijelaskan bahwa Umar mengartikan saran Rasulullah tentang menahan benda dengan memberi syarat atas benda yang diwakafkan dilarang untuk dijual belikan, diwariskan dan dihibahkan. Sehingga dengan adanya larangan ini mengisyaratkan bahwa pengalihan nama wâqif yang dilakukan dengan cara membeli benda wakaf untuk diwakafkan kembali oleh pembeli mutlak tidak diperbolehkan dalam Islam.

Namun dikarenakan suatu benda itu tidak selamanya akan utuh dan pasti mengalami kerusakan, maka dalam hal penjualan benda wakaf mash dipertentangkan oleh para ulama madzhab. Di mana dengan adanya pertentangan tersebut, menghasilkan banyak perbedaan pendapat antara madzhab yang satu dengan madzhab yang lainnya. ${ }^{47}$

Menurut pandangan jumhur ulama madzhab Syafi'i, mereka berpendapat bahwa menjual benda wakaf merupakan perkara yang dilarang dikarenakan yang diharapkan dari benda wakaf adalah kekekalannya. ${ }^{48}$ Dimana mereka merupakan salah satu madzhab yang sangat ketat dalam menghukumi penjualan benda wakaf itu sendiri. Bahkan seperti apapun keadaan benda wakaf, tetap harus dibiarkan begitu saja sampai benar-benar habis dengan sendirinya. ${ }^{49}$

\footnotetext{
${ }^{46}$ Muslim, Shahih Muslim 2, 72.

47 Ayudin, "Hukum Jual Beli Harta Wakaf", 67.

${ }^{48}$ Faishal Haq dan A. Saiful Anam, Hukum Wakaf, 39.

49 Departemen Agama, Fikih Wakaf, 77.
} 
Dari pernyataan di atas, dapat disimpulkan bahwa dalam pandangan jumhur ulama madzhab Syafi'i tersebut tidak ada celah atas kebolehan untuk melakukan mengalihkan nama wâqif dengan membeli benda wakaf untuk diwakafkan kembali atas nama dirinya.

Namun dalam pandangan lainnya, sebagian ulama madzhab Syafi'i memperbolehkan penjualan benda wakaf. Kebolehan tersebut adalah jika benda wakaf itu berupa benda bergerak yang telah rusak dan tidak dapat dimanfaatkan lagi oleh penerima wakaf, di mana hasil dari penjualannya dibelikan benda lain sebagai gantinya. Hal ini sebagaimana dinyatakan oleh Imam Al-Mawardi dan Al-Ramli dalam pendapatnya yang menyatakan bahwa benda wakaf bergerak yang rusak dan tidak dapat memberikan manfaat lagi bagi penerima wakaf dapat diperjual belikan dan dibelikan benda lain sebagai gantinya demi menghilangkan kemubadziran dari benda wakaf yang telah rusak. 50

Dari pendapat tersebut, masih ada kemungkinan untuk dilakukan pengalihan nama wâqif dengan membeli suatu benda wakaf untuk dijadikan wakaf kembali oleh pembelinya. Namun yang terjadi di masjid Istiqlal Desa Palengaan Daja, benda wakaf yang diperjual belikan berupa tiang masjid yang pada dasarnya tiang tersebut masih tergolong ke dalam benda bergerak karena masih berupa tiang saja yang memungkinkan untuk dipindah. Namun keadaan benda tersebut masih baru, dalam artian tidak rusak dan masih akan dimanfaatkan sebagai penyangga utama dalam pembangunan ulang masjid Istiqlal Desa Palengaan Daja itu sendiri.

Oleh karena itu, praktik pengalihan nama wâqif dengan cara penjualan benda wakaf untuk diwakafkan kembali oleh pembeli sebagaimana terjadi di masjid Istiqlal Desa Palengaan Daja adalah sebuah transaksi yang tidak diperbolehkan dalam hukum Islam menurut pandangan ulama madzhab Syafi'i.

50 Dahlia, "Studi Analisis Terhadap Dinamika Pemikiran Fukaha", 57. 
Adapun dalam pandangan ulama madzhab Maliki, mereka dalam menghukumi penjualan benda wakaf membedakan benda wakaf ke dalam dua bentuk, yakni benda bergerak dan benda tidak bergerak. Untuk benda bergerak ulama madzhab Maliki memiliki pendapat membolehkan dalam penjualan benda tersebut, yakni apabila benda wakaf yang dimaksud sudah rusak dan tidak dapat diambil manfaatnya lagi serta tidak ada harapan lagi untuk bisa dimanfaatkan oleh penerima wakaf, di mana hasil penjualannya dibelikan benda lain sebagai gantinya. ${ }^{51}$

Dari sini dapat disimpulkan bahwa dalam pandangan ulama madzhab Maliki masih terdapat peluang untuk melakukan pengalihan nama wâqif dengan membeli benda wakaf untuk diwakafkan kembali, yakni dalam hal benda bergerak yang sudah rusak dan tidak dapat diambil manfaatnya lagi oleh orang yang dituju dalam wakaf.

Semenata untuk benda tidak bergerak, ulama madzhab Maliki tidak memberikan celah dalam kebolehan pengalihan nama wâqif dengan cara membeli benda wakaf untuk diwakafkan kembali. Di mana dalam pandangan mereka tidak memperbolehkan penjualan benda wakaf kecuali dalam keadaan darurat seperti untuk pelebaran jalan. ${ }^{52} \mathrm{Hal}$ ini terdapat pengecualian pada benda tidak bergerak yang berada di dalam luar dan tidak ada harapan lagi untuk bisa diambil manfaatnya, di mana dalam hal ini benda wakaf tersebut dapat diperjual belikan. ${ }^{53}$ Oleh karena itu, untuk benda wakaf yang tergolong benda tidak bergerak yang sudah rusak dan tidak ada harapan lagi untuk dimanfaatkan kembali, ulama madzhab Maliki masih meberikan celah untuk melakukan pengalihan nama wâqif dengan cara membeli benda wakaf untuk diwakafkan kembali.

Adapun untuk benda wakaf berupa masjid, ulama madzhab Maliki melarang dengan ketat penjualan benda wakaf berupa

51 Ayudin, "Hukum Jual Beli Harta Wakaf", 69-70.

52 Ibid, 7I.

53 Dahlia, "Studi Analisis Terhadap Dinamika Pemikiran Fukaha", 56. 
masjid. Hal ini sebagaimana perkataan Al-Kalabi yang menyatakan bahwa ulama madzhab Maliki bersepakat atas kemutlakan larangan penjualan benda wakaf berupa masjid. ${ }^{54}$ Oleh karena itu, dalam hal ini ulama madzhab Maliki juga tidak memberikan celah dalam melakukan pengalihan wâqif dengan membeli benda wakaf berupa masjid untuk diwakafkan kembali atas nama pembeli. Sehingga praktik pengalihan wâqif dengan membeli benda wakaf untuk diwakafkan kembali sebagaimana terjadi di masjid Istiqlal Desa Palengaan Daja merupakan perbuatan yang tidak diperbolehkan dalam pandangan ulama madzhab Maliki. Hal ini dikarenkan benda wakaf yang diperjual belikan berupa tiang masjid yang pada dasarnya berlaku atas benda tersebut hukumhukum masjid. Sebagaimana dijelaskan bahwa hasil sumbangan yang diniatkan untuk pembangunan masjid, maka atas hasil sumbangan tersebut telah berlaku hukum masjid meskipun dilakukan tanpa adanya shighat. ${ }^{55}$

Adapun dalam pandangan ulama madzhab Hambali, mereka berpendapat bahwa penjulan benda wakaf dapat dilakukan jika benda terebut sudah rusak, berkurang dan tidak memenuhi fungsinya sebagai benda wakaf atau tidak dapat diambil manfaatnya lagi oleh orang yang dituju dalam wakaf. Hal tersebut dilakukan dengan dibelikan benda lain dari hasil penjualan sebagai ganti dari benda wakaf yang dijual. ${ }^{56}$

Dari pendapat di atas, dapat disimpulkan bahwa dalam pandangan ulama madzhab Hambali masih memberikan celah untuk melakukan pengalihan wâqif dengan membeli benda wakaf untuk diwakafkan kembali. Di mana hal tersebut dapat dilakukan pada benda wakaf yang rusak, berkurang dan tidak dapat memenuhi fungsinya lagi sebagai benda wakaf yang mungkin diperbaiki oleh pembeli untuk diwakafkan kembali.

\footnotetext{
${ }^{54}$ Ayudin, "Hukum Jual Beli Harta Wakaf", 56.

55 Muhibbul Aman Aly, Wakaf, Masjid, Pondok dan Madrasah, Artikel Keislaman, diakses dari ppssnh.malang. pesantren.web.id/cgi-bin/content.cgi/artikel/wakaf.singel, pada tanggal 15 Desember 2017 pukul 16.30.

${ }^{56}$ Dahlia, "Studi Analisis Terhadap Dinamika Pemikiran Fukaha", 57.
} 
Dalam konteks yang terjadi di masjid Istiqlal Desa Palengaan Daja, benda wakaf yang diperjual belikan berupa benda yang tidak rusak dan juga tidak berkurang. Adapun tidak adanya manfaat yang dapat diambil karena hanya sebatang tiang yang tegak adalah hal yang bersifat sementara saja, di mana benda tersebut akan digunakan sebagai penyangga utama dalam pembangunan ulang masjid Istiqlal Desa Palengaan Daja.

Oleh karena itu, praktik pengalihan wâqif dengan membeli benda wakaf untuk diwakafkan kembali oleh si pembeli agar menjadi wakaf penuh darinya merupakan perbuatan yang tidak diperbolehkan dalamhukum Islam menurut pandangan ulama madzhab Hambali. Terlebih lagi dalam pandangan sebagian ulama madzhab Hambali menyatakan bahwa penjualan benda wakaf berupa masjid merupakan perbuatan yang dilarang secara mutlak dalam Islam. Sebagaimana perkataan Abu Bakar yang diriwayatkan oleh Ali bin Abu Said bahwa penjualan benda wakaf berupa masjid adalah transaksi yang dilarang. ${ }^{57}$

Adapun dalam pandangan ulama madzhab Hanafi, pengalihan wâqif dengan membeli benda wakaf untuk diwakafkan kembali atas nama orang yang membelinya adalah sesuatu yang diperbolehkan. Hal ini sebagaimana dalam mereka bahwa penjualan benda wakaf dapat dilakukan oleh siapa saja, baik bendanya rusak atau tidak tetapi ada ganti yang menjanjikan, baik disyaratkan oleh wâqif atau tidak disyaratkan oleh wâqif, atau wâqif tidak menyinggung sama sekali. 58

Dari sini, ulama madzhab Hanafi lebih memberikan keleluasaan pada seseorang untuk melakukan pengalihan nama wâqif dengan cara membeli benda wakaf untuk diwakafkan kembali atas nama dirinya, baik itu benda wakaf yang dibeli rusak atau tidak rusak tetapi ada benda lain atau ganti lain yang menjanjikan.

Praktik pengalihan nama wâqif yang terjadi di masjid Istiqlal Desa Palengaan Daja merupakan transaksi yang diperbolehkan

57 lbid.

58 lbid, 55-56. 
dalam hukum Islam menurut pandangan ulama madzhab Hanafi. Hal ini dikarenakan dijualnya benda wakaf berupa tiang masjid memiliki ganti yang menjanjikan yang bisa digunakan sebagai bahan tambahan dalam menyelesaikan pembangunan masjid Istiqlal itu sendiri. Di mana hasil dari penjualan tersebut digunakan sebagai dana untuk membeli bahan dalam melanjutkan pembangunan masjid itu sendiri, yakni meneruskan pemasangan bata, lantai atas dan lain sebagainya.

Dari analisis hukum terkait dengan pengalihan nama wâqif dengan cara membeli benda wakaf untuk diwakafkan kembali oleh pembeli sebagaimana dijelaskan di atas, dapat dikatakan bahwa dalam pandangan madzhab Syafi'i, Maliki dan Hambali tidak diperbolehkan untuk dilakukan. Akan, tetapi dalam pandangan ulama madzhab Hanafi hal itu dapat dilakukan dengan keleluasaan yang diberikan mereka dalam menghukumi penjualan benda wakaf itu sendiri.

Namun dari kesimpulan pertama tersebut, perlu dikaji dari perspektif hukum muamalahnya. Di mana dalam perkara muamalah tentang jual beli, terdapat rukun dan syarat yang harus dipenuhi agar transaksi yang dilakukan benar-benar sah menurut hukum Islam. Secara umum, dengan melihat praktik jual beli benda wakaf di masjid Istiqlal Desa Palengaan Daja sudah memenuhi rukun jual beli, yakni adanya orang yang berakad (penjual dan pembeli), adanya objek akad (benda yang diperjual belikan), shighat (ijab dan qabul), dan nilai tukar. ${ }^{59}$

Adapun berkaitan dengan syarat jual beli, maka dalam praktik penjualan benda wakaf yang terjadi di masjid Istiqlal perlu dikaji lebih dalam lagi. Di mana salah satu syarat yang terdapat dalam jual beli adalah benda yang diperjual belikan harus dapat diserahkan kepada pembeli dan berada dalam kepemilikan seseorang (hak jual), sehingga jual beli dapat dikatakan sah jika memenuh syarat ini dalam praktiknya.

${ }^{59}$ R. Abdul Djamali, Hukum Islam Berdasarkan Ketentuan Kurikulum, I 47- I 53. 
Jika dilihat dalam pandangan ulama madzhab Syafi'i, Hambali dan Maliki sebagaimana dijelaskan di atas bahwa benda wakaf yang diperjualbelikan di masjid Istiqlal Desa Palengaan Daja merupakan benda yang tidak dapat diperjual belikan, dikarenakan benda tersebut masih belum memenuhi kriteria-kriteria tertentu terkait dengan benda wakaf yang dapat diperjualbelikan.

Oleh karena itu, praktik jul beli yang terjadi di masjid Istiqlal Desa Palengaan Daja merupakan perkara yang dilarang dalam pandangan hukum Islam menurut ulama Madzhab Syafi'i, Hambali dan Maliki. Hal ini dikarenakan kehahalan jual beli itu sendiri merupakan transaksi yang diperbolehkan apabila tidak ada dalil yang mengharamkannya. Sebagaimana hal ini tertera dalam keumuman kaidah fiqih yang menyatakan:

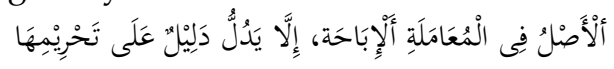

"Hukum asal dalam hal muamalah adalah mubah, kecuali ada dalil yang mengharamkannya".60

Oleh karena itu, dalam praktik jual beli yang terjadi di masjid Istiqlal Desa Palengan Daja merupakan transaksi yang dilarang dalam hukum Islam menurut pandangan ulama madzhab Syafi'i, Maliki dan Hambali, dikarenakan benda tersebut masih tergolong ke dalam benda yang dilarang untuk diperjualbelikan karena tidak memenuhi syarat benda wakaf yang dapat diperjual belikan.

Larangan tersebut dikembalikan pada hukum awal penjualan benda benda wakaf, bahwa pejualan benda wakaf pada asalnya merupakan perkara yang dilarang. Sebagaimana larangan ini didasarkan pada adanya dalil yang dikutip peneliti pada awal pembahasan subbab ini, yakni hadits yang diriwayatkan oleh Imam Bukhori dan Muslim dari Ibnu Umar yang menceritakan tentang wakaf umar dengan syarat bendanya tidak boleh dijual, diwariskan dan tidak boleh dihibahkan. ${ }^{61}$

${ }^{60}$ Yusuf al-Qordlawi, Tujuh Kaidah Utama Fiqih Muamalat, (Jakarta: Pustaka Al Kautsar, 2014 ), 9. 61Muslim, Shahih Muslim 2, 72. 
Terlebih lagi dalam pandangan ulama madzhab Syafi'i dan Hambali menyatakan bahwa benda yang sudah diwakafkan pada dasarnya terlepas kepemilikannya dari wâqif dan menjadi milik Allah Taala. ${ }^{62}$ Begitu juga dalam pandangan ulama madzhab Maliki yang menyatakan bahwa benda yang sudah diwakafkan untuk selamanya seperti masjid itu sendiri merupakan benda yang kepemilikannya terlepas dari wâqif. ${ }^{63}$

Oleh karena itu, dapat disimpulkan bahwa sejatinya wâqif tidak memilik hak untuk menjual benda wakaf. Begitu juga dengan nâdzir wakaf, benda wakaf yang dipercayakan padanya untuk dikelola tidak menyebabkan perpindahan hak milik benda wakaf tersebut padanya. Hal ini berdasarkan UU. No. 41 Tahun 2004 tentang Wakaf, dalam Pasal 3 ayat (2) menentukan bahwa terdaftarnya harta benda wakaf atas nama nâdzir tidak membuktikan kepemilikan nadzir atas benda tersebut. ${ }^{64}$

Dengan demikian, seorang nâdzir juga tidak memiliki hak milik atas benda wakaf yang dikelonya. Namun pada dasarnya nadzir memiliki hak jual jika sudah mendapat ijin dari hakim sebagaimana hal ini dinyatakan oleh ulama madzhab Hambali65, yang dalam hukum yang berlaku di Indonesia hal itu diqiyaskan pada Menteri dan Badan Wakaf Indonesia. Di mana nâdzir sebagai pengelola benda wakaf dapat menjual benda wakaf jika mendapat ijin dari Menteri dan BWI. ${ }^{66}$

Namun untuk dapat menjual benda wakaf itu sendiri, terdapat beberapa syarat yang harus dipenuhi untuk menjadi benda wakaf yang dapat diperjual belikan. Namun pada kenyataannya, praktik jual beli benda wakaf di masjid Istiqlal Desa Palengaan Daja belum memenuhi syarat tersebut sehingga masih memiliki hukum yang

\footnotetext{
62 Isfandiar, "Tinjauan Fiqh Muamalat dan Hukum Nasional", 54.

${ }^{63}$ Suchamdi, "Eksistensi (Qabul) Penerimaan Dalam Akad Wakaf", 32.

${ }^{64}$ Undang-Undang Nomor 41 tahun 2004 tentang Perwakafan, dalam Kompilasi Hukum Islam (Hukum Perdata, Kewarisan, dan Perwakafan), (Bandung: Nuansa Aulia, 20।5), I 40.

${ }^{65}$ Ayudin, "Hukum Jual Beli Harta Wakaf, 74-75.

66 Undang-Undang Nomor 4 I tahun 2004 tentang Perwakafan, II 6- 117.
} 
sama dengan hukum asalnya, yakni dilarang untuk dijual dalam pandangan ulama madzhab Syafi'i, Maliki dan Hambali.

Argumenatasi larangan tersebut karena pihak yang menjual benda wakaf di masjid Istiqlal Desa Palengaan Daja merupakan pihak yang tidak memiliki hak jual atas benda yang diperjual belikan. Sedangkan dalam hukum muamalahnya, salah satu syarat jual beli adalah penjual merupakan pemilik atau orang yang memiliki hak jual atas benda yang dijualnya. ${ }^{67}$

Dalam hukum Islam, menjual sesuatu yang bukan miliknya atau tidak memiliki hak atas benda yang akan dijual merupakan transaksi yang dilarang. Hal ini berdasarkan hadits yang diriwayatkan oleh Abu Daud, Tirmidzi, Nasa'i dan Ibnu Majah dari Hakim bin Hizam bahwa ia bertanya pada Rasulullah:

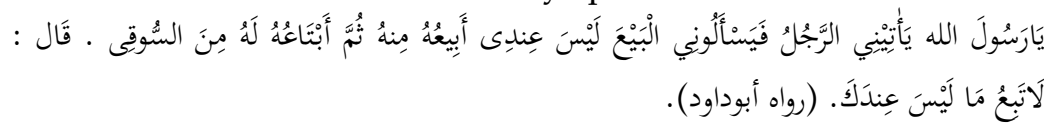

"Wahai Rasulullah, ada seseorang yang mendatangiku seraya meminta kepadaku agar aku menjual kepadanya barang yang belum aku miliki dengan cara terlebih dahulu aku membelinya untuknya dari pasar? Maka Rasulullah menjawab: Janganlah engkau menjual sesuatu yang tidak ada padamu". (H.R. Abu Daud). ${ }^{68}$

Hadits di atas menjelaskan bahwa pada dasarnya dalam hukum Islam seseorang dilarang menjual benda yang bukan miliknya atau tidak meiliki hak jual atas bendanya, dikarenakan jual beli merupakan transaksi yang mengakibatkan perpindahan hak milik yang tentunya harus dilakukan oleh pemiliknya atau oleh seseorang yang sudah mendapatkan kuasa dari pemiliknya.

Di sisi lain dalam hukum positif yang berlaku di Indonesia, dikenal sebuah asas hukum yang menyatakan bahwa tidak seorang

67 Shobirin, "Jual Beli Dalam Pandangan Islam", 248.

${ }^{68}$ Abu Daud Sulaiman, Shahih Sunan Abu Daud, dalam Ensiklopedia Hadits 5 Sunan Abu Daud, ed. Muhammad Ghazali, et. Al. (Jakarta: Almahira, 2013), 74l. 
pun dapat mengalihkan lebih banyak haknya dari pada yang ia miliki (nemo plus juris tranfere protest quam ipse habet). ${ }^{69}$

Asas hukum di atas memberikan pengertian bahwa pada dasarnya seseorang yang tidak memiliki hak atas suatu barang tertentu, maka orang tersebut tidak dapat mengalihkan benda yang bukan haknya dalam bentuk apapun. Hal ini dikarenakan setiap pengalihan hak perlu dilakukan oleh orang yang berhak atas objek pengalihan tersebut atau orang yang diberikan kuasa atasnya. Termasuk dalam hal ini adalah melakukan transaksi jual beli, di mana transaksi tersebut merupakan salah satu transaksi yang mengakibatkan pengalihan hak atas suatu benda tertentu.

Oleh karena itu dalam pandangan ulama madzhab Syafi'i, Hambali dan Maliki, praktik jual beli yang terjadi di masjid Istiqlal Desa Palengaan Daja merupakan jual beli bathil, yakni jual beli yang dilarang oleh syariat karena tidak memenuhi satu atau lebih rukun dan syarat jual beli. ${ }^{70} \mathrm{Di}$ mana dalam praktik yang ada di lapangan tidak memenuhi satu salah satu syarat jual beli, yakni penjual bukanlah orang yang memiliki hak atas benda yang diperjualbelikan.

Di sisi lain, praktik tersebut juga mengandung kefashid-an di dalamnya. Di mana di dalam praktik yang dilakukan, benda yang diperjual belikan merupakan benda yang dilarang untuk dijual dalam hukum Islam. Adapun menurut pandangan ulama madzhab Hanafi, jual beli yang terjadi di masjid Istiqlal Desa Palengaan Daja merupakan jual beli yang shahih, yakni jual beli yang diperbolehkan karena sudah memenuhi rukun dan syarat jual beli itu sendiri. ${ }^{71}$

Sebagaimana telah dijelaskan sebelumnya bahwa benda wakaf yang diperjualbelikan di masjid Istiqlal Desa Palengaan Daja merupakan benda wakaf yang sudah memenuhi kriteria benda

${ }^{69}$ Umi Supraptiningsih, Pengantar Hukum Indonesia, (Pamekasan: STAIN Pamekasan Press, 2009), 18.

70 Siswadi, "Jual Beli dalam Perspektif Islam", Jurnal Ummul Qura, 2 (Agustus, 2013), 64.

71 lbid. 
wakaf yang dapat diperjual belikan. Selain itu dalam pandangan mereka, penjualan benda wakaf itu boleh dilakukan oleh siapa saja. ${ }^{72}$

Pendapat ini menunjukkan bahwa nadzir dan para pihak yang melakukan penjualan benda wakaf tersebut pada dasarnya sudah memiliki hak atas penjualan benda wakaf. Terlebih lagi nadzir merupakan orang yang memang ditugaskan dalam pengelolaaan dan pengembangan benda wakaf. Di mana salah satu tugas nâdzir adalah mengelola dan mengembangkan harta benda wakaf sesuai dengan tujuan dan peruntukannya. ${ }^{73}$ Oleh karena itu, dari hal tersebut dapat disimpulkan bahwa praktik jual beli yang terjadi di masjid Istiqlal Desa Palengaan Daja merupakan transaksi yang diperbolehkan dalam pandangan ulama madzhab Hanafi.

\section{Penutup}

Berdasarkan hasil penelitian tentang jual beli benda wakaf dalam rangka menarik sumbangan pembangunan masjid Istiqlal Desa Palengaan Daja, dapat disimpulkan sebagai berikut: pertama Praktik jual beli benda wakaf di masjid Istiqlal Desa Palengaan Daja berawal dari adanya sumbangan masyarakat untuk renovasi total masjid tersebut dengan cara membangun ulang, di mana pada tahap awal terbentuk pondasi masjid dan beberapa tiang dari hasil sumbangan berbagai masyarakat. Kemudian benda wakaf berupa tiang masjid yang baru terbentuk tersebut diperjualkan oleh masyarakat setempat agar menjadi wakaf dari orang yang membelinya. Kedua Pandangan hukum Islam terhadap jual beli benda wakaf di Masjid Istiqlal Desa Palengaan Daja merupakan perbuatan yang tidak diperbolehkan dalam pandangan ulama madzhab Syafi'i, Maliki dan Hambali, dikarenakan benda yang diperjual belikan bukanlah benda yang termasuk dalam kategori benda yang dapat diperjualbelikan dalam pandagan mereka. Selain itu dalam pandangan mereka praktik jual beli yang dilakukan

\footnotetext{
72 Ayudin, "Hukum Jual Beli Harta Wakaf, 75.

73 Undang-Undang Nomor 4 I Tahun 2004, 4.
} 
adalah jual beli yang bâthil, dikarenakan tidak memenuhi syarat jual beli yaitu penjual bukan orang yang meiliki hak jual atas benda tersebut. Sementara dalam pandangan ulama madzhab Hanafi hal itu diperbolehkan, dikarenakan sudah terdapat ganti yang menjanjikan atas penjualan benda wakaf tersebut sebagai salah satu syarat sebagai benda wakaf yang dapat diperjualbelikan. Selain itu dalam hal muamalahnya sudah termasuk jual beli yang sahih, yakni memenuhi rukun dan syarat jual beli.

\section{Daftar Pustaka}

Ayudin. “Hukum Jual Beli Harta Wakaf Dalam Perspektif Empat Imam Madzhab (Imam Maliki, Imam Hanafi, Imam Shafi'i dan Imam Hambali)". Maqosid. 2. Juli, 2016.

Asy'ari, M. Khoirul Hadi Al. "Pandangan Ibn Qudamah Tentang Wakaf Dan Relevansinya Dengan Wakaf Di Indonesia". Li Falah Jurnal Studi Ekonomi dan Bisnis Islam. 1. Juni, 2016.

Abdullah, Lukman Haji. "Istibdal Harta Wakaf Dari Perspektif Mazhab Syafi'e". Jurnal Figh. 7. 2010.

Departemen Agama. al-Quran Perkata dan Tajwid Warna Rabbani. Jakarta: PT. Surya Prisma Sinergi, 2012. . Fiqih Wakaf. Jakarta: Direktorat Pemberdayaan Wakaf Departemen Agama RI, 2007.

Baihaqy, Abu Bakar Ahmad bin Husain bin Ali al. al-Sunan al-Kabir Juz 6. Beirut: Dar al-Kutub al-Ilmiyah, 2003.

Holis, Mohammad. “Konstruksi Masyarakat Pencari Sumbangan Di Jalan Raya (Studi Kasus Pencarian Amal Masjid Di Jalan Raya Kabupaten Pamekasan)". Nuansa, 1. Januari-Juni, 2017.

Haq, Faishal dan A. Saiful Anam. Hukum Wakaf dan Perwakafan di Indonesia. Pasuruan: PT. Garoeda Buana Indah, 1993.

Muslim. al-Kutub al-Sittah: Shahih Muslim 2. dalam Ensiklopedia Hadits 4 Shahih Muslim . ed. Masyhari. et. Al. Jakarta: Almahira, 2012. 
Ma'u, Dahlia Haliah. "Studi Analisis Terhadap Dinamika Pemikiran Fukaha Sunni Tentang Ibdâl Dan Istibdâl Benda Wakaf". Al'Adala. 1. Juni, 2016.

Sakinah. Fiqih Muamalah. Pamekasan: STAIN Pamekasan Press, 2006.

Sarwat, Ahmad. Seri Fiqih Kehidupan (12): Masjid. Jakarta: DU Publishing, 2011.

Satori, Djam'an dan Aan Komariah. Metodologi Penelitian Kualitatif. Bandung: ALFABETA, 2017.

Siswadi. “Jual Beli dalam Perspektif Islam”. Jurnal Ummul Qura. 2. Agustus, 2013.

Suhendi, Hendi. Fiqih Muamalah. ed-I, cet-VIII. Jakarta: Rajawali Pers, 2013.

Sulaiman, Abu Dawud. Al-Kutub Al-Sittah; Sunan Abu Dawud. dalam Ensiklopedia Hadits 5; Sunan Abu Dawud. ed. Muhammad Ghazali. et. Al. Jakarta: Almahira, 2013.

Supraptiningsih, Umi. Pengantar Hukum Indonesia. Pamekasan: STAIN Pamekasan Press, 2009.

Wardi, Moch. Cholid. "Pencarian Dana Masjid Di Jalan Raya Dalam Perspektif Hukum Islam”. al-Ihkam. 2. Desember, 2012.

Zuhayly, Wahbah. al-Figh al-Islami wa Adillatuhu. vol. 8. Damaskus:

Dar al-Fikr, 1985.

Intruksi Presiden R.I. Nomor 1 Tahun 1991 Kompilasi Hukum Islam di Indonesia.

Undang-Undang Nomor 41 Tahun 2004 Tentang Perwakafan.

Aly, Muhibbul Aman. Wakaf, Masjid, Pondok dan Madrasah. Artikel

Keislaman. diakses diakses dari

ppssnh.malang.pesantren.web.id/cgi-

bin/content.cgi/artikel/wakaf.singel. pada tanggal 15

Desember 2017 pukul 16.30. 